\title{
A FEW REFLECTIONS ON CONTEMPORARY SCIENCE EDUCATION AND EDUCATIONAL RESEARCH
}

\author{
Katarzyna Potyrała \\ Pedagogical University of Krakow, Poland \\ E-mail: katarzyna.potyrala@up.krakow.pl
}

Educational tendencies are certain regularities outlined in the development of ideas related to education and upbringing. They show some perspectives that can be predicted by describing models, planning research on future processes as well as taking preventive actions. Trends are more, than tendencies, related to the style of some types of research or their directions conditioned by social demand or the specificity of cultural changes at a given time and place.

Contemporary science education tendencies are largely due to the globalization process, technology development, multiculturalism and human impact on the natural environment. The old slogans such as "Live globally, act locally", "Sustainable development in practice" or "Multicultural path to success" still seem to be a big challenge. We see a number of problems that remain unsolved, and even grow, in the situation of rapid development of knowledge, social change and global climate issues.

In response to various calls, local organizations, business, NGOs and other institutions have initiated a big number of activities for natural environment. However, it seems that the school and university do not comment them, rarely undertake joint research problems and challenges facing education. Inclusion, social participation, augmented reality relations, outdoor science education, sustainable development, competence and metacognition can still be found on the "top of the top" list regarding the need for educational research. It seems that school is too overwhelmed by the progress and speed of change, teachers are obliged to implementation a narrowly understood curriculum. Observations and interviews with teachers show that they are more interested in the degree of acquiring programme material by students, than thoroughly thought-out work on the development of students' interest in creative activity, the necessity in it, which predetermines the development of creative abilities (Uzakbaeva at al. 2013). In general, additional activities can only be taken as part of external projects whose beneficiary is the school community but an external institution there is a leader.

Still is current that taking into account the broad context of education, awareness of its variability, areas of various tensions, definitely cut off the presented multi-context approach to teaching practice from those views that consider teaching in a contextual, narrow categories of craft, proficiency or advanced technology (Gołębniak, 1998).

For educators, the research related to their practical skills, students' achievements and the impact of teachers' activities on the education of the young generation are often closer to them. These studies are equally important, especially in the time of the educational system reform and program changes. Particularly important are the research on the selection, structure of the teaching and learning content, ways of transformation of university knowledge at lower stages of education, the impact of media on teaching and learning outcomes, new ways of evaluating the teaching process and the „competences of the future” of teachers and students (e.g. creativity, communication). Formation of creative competence of the person is one of the contemporary problems for both the modern society as a whole and for the individual, in particular for the educational system (Uzakbaeva at al, 2013). Communicative competence of 
the teachers includes effectively solving skills of social and psychological problem situations in the professional and personal spheres (Yermentaeyeva at al, 2014). These skills seem crucial today, and practice requires strengthening with responsible research in this area and the connection with teacher training. Ngema and Lekhethothe (2019, p. 759) underline centrality of well-qualified, competent teachers to learners' academic success and the need for teacher training institutions to improve their admissions selectivity and for school authorities to be selective when appointing teachers.

In 2009, Henry Jenkins, in the report connected with the digital media and learning (Confronting the Challenges of Participatory Culture Media Education for the 21st Century) wrote about educational challenges related to problem solving, team work related to the tasks and developing new knowledge, for example during Wikipedia or digital games using. He indicated some benefits regarding these forms of participation culture, including the possibility of using each other, diversifying cultural expression, developing skills valued in the modern world and workplaces, and a more intense concept of citizenship. We are coming back to these ideas today by popularizing gamification, new learning programs through games and more and more frequent testing of such ideas during experimental classes. Some authors, from years, see great potential in games in particular for science education, for example Honey and Hilton (2011, p.1) suggest that 'they enable learners to see and interact with representations of natural phenomena that would otherwise be impossible to observe'.

Gamification in education cannot be contrary to cooperative (social) learning, it cannot focus only on cooperation with a computer. Too often today we only feel the declarative commitment of young people to social issues. Especially on social networks, all you have to do is mark interest in the action or click "I like it".

According to Jenkins, access to the participation culture functioning as a new form of hidden curriculum, shapes the successes of young people. Some scientists say, however, that children and youth, by achieving these key skills and competences, interact too much with popular culture. There are some fears which suggest the need for pedagogical research, namely: gaps and appearances of participation, unequal access to opportunities, experiences, skills and knowledge that will prepare young people for full participation in tomorrow's world, and the challenges connected with learning and recognizing the ways (manipulations), through which the media shape the perception of the world. An important issue is also ethical challenges: the collapse of traditional forms of vocational training and socialization, as well as the traditional norms of social life, new ethical standards, the fall of traditionally understood authorities (teachers, parents). Jenkins (2009, p. 13) says that schools and out-of-school programs must devote more attention to supporting what we call new media skills: cultural competences and social skills that young people need in a new media environment. Participation culture transfers concentration from individual expression to community involvement. New skills include social skills developed through collaboration and they are based on knowledge and research, technical and critical thinking skills acquired during school science education. Experts agree that critical-thinking behaviors imply an open-minded tendency to analyze, synthesize, and evaluate information in order to solve problems and make resolutions (Alghafri \& Ismail, 2014). Working on free social networks is a great way to understand „our times” (Giordan, 2018). Giordan asks: Are there ,good reasons“ to completely ban smartphones at school? [...] Why immediately fall into fear, anxiety and even fear? And if we look at this tool again? Why not make it a subject of study? Or maybe we will put a smartphone in the school curriculum?

Students perceive the presence of other people (friends) in their educational experience as an important part of this experience, and they perceive the virtual environment as a natural space for collective pro-social activities. The school should use those skills that are considered key in a knowledge-based society, and not ignore the needs of students in learning and building relationships (Potyrała, 2019). 
PROBLEMS

OF EDUCATION

IN THE $21^{\text {st }}$ CENTURY

Vol. 78 , No. 1,2020

6

Modern science education, based on the idea of education for action and in action must take into account a lot of educational approaches and contexts, the diversity of communication practices and cooperation between people involved in the processing of scientific information in the real and virtual world (Potyrala, 2017, p. 281)

It is still current to confront educational models described by didactics a few or several years ago with the current educational reality. This is an interesting area of research - educational reconstruction model (Kattmann et al.), allosteric model (Giordan), The Action for Climate Empowerment (UNESCO 2016) and others. How do these models and guidelines for accelerating solutions through education, training and awareness-raising work in the face of changes in the modern world, overproduction of information, broadly understood informal education and the dominant role of new media?

And what about neurodidactics, a relatively young discipline, some kind of bridge between neuroscience and didactics, "didactics of the 21st century"? (Petlák, 2012). According to Petlák (2012), many aspects of neuropedagogy and neurodidactics are very interesting especially in the context of the effective learning but on the other hand one can remark, that both of the neurosciences introduced to a pedagogy do not ensure an affective learning, because it is not determined by the neuronal factors only, but other factors too. Many scientists comment the positions represented by neurodidactics and the status of neuropedagogy, we need to take a closer look at this in the context of in-depth interdisciplinary research. Undoubtedly, new tools used by teams of neurodidactics allow for conducting promising pedagogical research increasing the level of understanding of the conditions of the learning and teaching process.

We need to undertake also more research on alternative models of science and environmental education in augmented reality and education for science culture and sustainable development. Current research reveals numerous antinomies and, among others, opens a broader discussion on human addiction to nature and its simultaneous destruction and even destruction. Nature also appears as the work of a man with new technologies, but also as a creation of social activities. All threads reveal the cultural entanglement of man in matters of nature, which he is, and which he changes (Popczyk, 2011). The natural environment influences the shape of civilization in a fundamental, not incidental way. In addition, creating the environment is limited, and thus illusory - a civilization perceived as independent of natural conditions is contrary to its own nature (Diec, 2011). Ecological awareness, combined with aesthetic sensitivity, can help to recognize and respect nature, both intact by man and that in which man interferes. To see beauty, you need to understand the natural relationships and relationships of man with the environment in which he lives (Głutkowska-Polniak, 2011). Don't let Greta Thunberg's message to go unnoticed by science teachers and researchers in science and environmental education.

It is often underlined that sustainable development means a new way of thinking about the world, and despite conceptual and political uncertainty is a concept, despite doubts about the instruments to be adopted for its implementation, despite the difficulties with articulation and determining the appropriate executive scales, despite the many actors and the ubiquitous conflicts that characterize their relations, sustainable development has acquired a global dimension that is necessary to emphasize the importance of certain contradictions. Educational research is a basic condition for raising the level of educational practice at all levels of teaching and learning. These studies should be some starting point for science and environmental awareness shaping and examining educational trends and their social implications.

Let me quote the words from the preface to the study Rethinking Education Towards a global common good? published by UNESCO in 2015 (p.3): 
The world is changing-education must also change. Societies everywhere are undergoing deep transformation, and this calls for new forms of education to foster the competencies that societies and economies need, today and tomorrow. This means moving beyond literacy and numeracy, to focus on learning environments and on new approaches to learning for greater justice, social equity and global solidarity. Education must be about learning to live on a planet under pressure. It must be about cultural literacy, on the basis of respect and equal dignity, helping to weave together the social, economic and environmental dimensions of sustainable development.

\section{References}

Alghafri, A. S. R., \& Ismail, H. N. B. (2014). The effects of integrating creative and critical thinking on school students' thinking. International Journal of Social Science and Humanity, 4(6), 518-525. https://doi.org/10.7763/IJSSH.2014.V4.410

Diec, J. (2011). Przyroda a cywilizacja [Nature and civilization]. Kultura współczesna, 2, 25-33

Kattmann, U., Duit, R., Gropengießer, H., \& Komorek, M. (1997). Model rekonstrukcji dydaktycznej ramy dla badań naukowych i rozwoju dydaktycznego [Didactic reconstruction model - framework for scientific research and didactic development]. Journal of Science Didactics, 3 (3), 3-18.

Giordan, A. (1996). From constructivism to allosteric learning model. In UNESCO Conference on Science Education 2000+. https://www.andregiordan.com/apprendre/From-constructivisme-to-allostericlearning-model1.pdf

Giordan, A. (2018). Le smartphone, un outil d'apprentissage... Educavox: Le média des acteurs de l'Ecole [The smartphone, a learning tool ... Educavox: The media for school stakeholders]. https://www. educavox.fr/accueil/debats/le-smartphone-un-outil-d-apprentissage

Głutkowska-Polniak, A. (2011). Przyroda w ujęciu estetyki ekologicznej Allena Carlsona [Nature in terms of ecological aesthetics by Allen Carlson]. Kultura Współczesna, 2, 34-42

Gołębniak, B. D. (1998). Zmiany edukacji nauczycieli: wiedza-biegłość-refleksyjność [Changes in teacher education: knowledge - fluency - reflectivity]. Edytor.

Hilton, M., \& Honey, M. A. (2011). Learning science through computer games and simulations. Washington, DC: National Academies Press.

Fleischman, K., \& Ariel, E. (2016). Gamification in science education: Gamifying learning of microscopic processes in the laboratory. Contemporary Educational Technology, 7(2), 138-159. https://files. eric.ed.gov/fulltext/EJ1106923.pdf

Jenkins, H. (2009). Confronting the challenges of participatory culture media education for the 21 st century. http://digilib.umpalopo.ac.id:8080/jspui/bitstream/123456789/315/1/\%5BHenry_Jenkins\%5D_ Confronting_the_Challenges_of_Part\%28BookZZ.org\%29.pdf

Ngema, M., \& Lekhetho, M. (2019). Principals' role in managing teacher professional development through a training needs analysis. Problems of Education in the 21st Century, 77(6), 758-772. https://doi.org/10.33225/pec/19.77.758

Petlák, E. (2012). Neuropedagogika i neurodydaktyka-tendencje XXI wieku [Neuropedagogy and neurodidactics-trends of the 21st century]. Chowanna, 39(2), 59-66.

Popczyk, M. (2011). Przemyśleć przyrodę [Think about nature]. Kultura wspótczesna, 2, 21-24.

Potyrała, K. (2017). iEdukacja. Synergia nowych mediów i dydaktyki. Ewolucja, antynomie, konteksty [iEducation. Synergy of new media and didactics. Evolution, antinomies, contexts]. Wydawnictwo Naukowe Uniwersytetu Pedagogicznego.

Potyrała, K. (2019). Internet i uczestnictwo społeczne w świetle relacji uczeń-nauczyciel [Internet and social participation in the light of student-teacher relations]. In J. R. Paśko (Ed.), Nauczyciel i uczeń we wspótczesnej szkole [Teacher and student in contemporary school] (pp. 11-22). Wydawnictwo Małopolskiej Wyższej Szkoły Ekonomicznej.

Rethinking education towards a global common good? (2015). UNESCO. https://unevoc.unesco.org/eforum/RethinkingEducation.pdf

Uzakbaeva, S., Baimukhanbetov, B., Berkimbaev, K., Mukhamedzhanov, B., \& Pralieva, R. (2013). To the problem of forming creative competence of future teachers. Creative Education, 4(03), 234240. http://dx.doi.org/10.4236/ce.2013.43034 
Katarzyna POTYRAŁA. A few reflections on contemporary science education and educational research

PROBLEMS

OF EDUCATION

IN THE $21^{\text {st }}$ CENTURY

Vol. 78 , No. 1,2020

Yermentaeyeva, A., Aurenova, M. D., Uaidullakyzy, E., Ayapbergenova, A., \& Muldabekova, K. (2014). Social intelligence as a condition for the development of communicative competence of the future teachers. Procedia-Social and Behavioral Sciences, 116, 4758-4763. https://doi.org/10.1016/j. sbspro.2014.01.1021

Received: December 22, 2019

Accepted: January 30, 2020

Cite as: Potyrała, K. (2020). A few reflections on contemporary science education and educational research. Problems of Education in the $21^{\text {st }}$ Century, 78(1), 4-8. https://doi. org/10.33225/pec/20.78.04

Katarzyna Potyrała

Dr hab., Professor, Head of Department of Didactics and Methodology of Educational Research, Institute of Educational Sciences, Pedagogical University of Krakow, ul Ingardena 4, 30-060 Krakow, Poland.

E-mail: katarzyna.potyrala@up.krakow.pl

Website: https://scholar.google.com/citations?user=y5ogVosAAAAJ\&hl=pl 